\title{
IMPLEMENTASI METODE ELECTRE UNTUK PEMILHAN PONDOK PESANTREN
}

\section{IMPLEMENTATION OF ELECTRE METHOD FOR MUSLIM BOARDING SCHOOL SELECTION}

\author{
Maolana Fatkhurrizqi ${ }^{1}$, Wiwien Hadikurniawati ${ }^{2}$ \\ Program Studi Teknik Informatika \\ Universitas Stikubank Semarang \\ Email: maoellana0@gmail.com
}

\begin{abstract}
Abstrak
Pondok pesantren merupakan pendidikan rujukan alternatif bagi para pelajar yang ingin mendalami ilmu agama islam. Persaingan teknologi dari beberapa pondok pesantren salafi dan moderen menjadikan suatu kebimbangan dalam memilih pondok pesantren yang sesuai dengan kriteria. Kebingungan dan kebimbangan dari calon siswa dan orangtua tersebut mendorong untuk dibangunnya suatu system atau aplikasi untuk memilih pondok pesantren dengan beberapa kriteria dan alternative. Penelitian ini bertujuan untuk memberikan solusi alternative yang sesuai dengan keinginan dan harapan calon siswa dan orang tua dalam menentukan pondok pesantren. Sistem yang dibangun mampu memberikan rekomendasi alternative pondok pesantren dengan menggunakan metode ELECTRE. Metode ini merupakan metode outranking berdasarkan analisis concordance (kesesuaian). Metode ELECTRE dapat mengolah informasi menjadi suatu alternative yang baik dan sekaligus membuat perangkingan pada serangkaian alternative, sehingga mampu memberikan hasil berupa alternative yang paling optimal.
\end{abstract}

\section{Kata kunci : SPK, Electre, Pemilihan Pondok Pesantren}

\begin{abstract}
Islamic boarding schools are an alternative reference education for students who want to explore Islamic religious knowledge. Technological competition from several Salafi and modern Islamic boarding schools has made a doubt in choosing a boarding school that fits the criteria. Confusion and confusion from prospective students and parents encourage the construction of a system or application to select a boarding school with several standards and alternatives. This study aims to provide alternative solutions by prospective students' and parents' wishes and expectations in determining Islamic boarding schools. The
\end{abstract}


system built can provide recommendations for alternative boarding schools using the ELECTRE method. This method is an outranking method based on concordance analysis. The ELECTRE method can process information for a suitable alternative and simultaneously rank various other options to provide the most optimal choice.

\section{Keywords: SPK, Electre, Moslem Boarding School}

\section{PENDAHULUAN}

Pendidikan pesantren saat ini semakin terstruktur dan pendidikan semakin berkembang dengan menawarkan kurikulum ganda berupa kurikulum dari kemendikbud dan kurikulum dari kemenag [1]. Pesantren pada umumnya memiliki satu kesatuan kesamaan dengan pondok pesantren yang lainnya, baik itu persamaan dalam ideologi maupun persamaan oleh referensi pada metode yang diajarkannya.

Semakin banyak pondok pesantren bermunculan dengan menawarkan kelebihan-kelebihannya guna menarik calon siswa [2]. Pemilihan pondok pesantren terbaik dilakukan secara spesifik dari berbagai kriteria mulai dari kurikulum pendidikan, fasilitas pondok pesanten, ekstrakurikuler dan kegiatan-kegiatan lainya. Hal ini menjadi suatu masalah bagi para calon siswa dan orang tua dalam menentukan pilihan. Kebingungan dan kebimbangan dalam menentukan pilihan pondok pesantren dari sekian banyaknya alternatif yang ada menjadi dasar perlunya dibangun suatu system yang membantu dalam menentukan alternatife terbaik. Harapannya agar dalam menentukan pondok pesantren yang terbaik tidak merupakan faktor subyektifitas dari para pengambil keputusan.

Perkembangan serta pemanfaatan teknologi yang semakin maju dan berkembang dapat dimanfaatkan dalam sektor lembaga pendidikan, yang merupakan suatu pilihan yang paling tepat dalam kemajuan zaman untuk menuntut kecepatan, kemudahan serta mengurangi rasa beban dalam aktivitasnya [3]. Khususnya dalam Pondok Pesantren untuk memberikan informasi terkait pondok pesantren terbaik berdasarkan pengolahan data pada setiap kriterianya dengan menggunkan suatu metode tertentu. Pengolahan informasi tersebut dapat menghasilkan informasi yang lebih akurat serta terkomputerisasi [4]. Memilih pondok pesantren yang tepat sesuai kriteria yang diharapkan calon siswa menjadi salah satuhal yang sangat penting. Maka dari itu diperlukannya suatu system yang mampu menjadikan rekomendasi alternatif pondok pesantren [5].

System Pengambil Keputusan (SPK) merupakan sebuah system 
mekanisme yang interaktif untuk penyedia informasi, pemodelan data serta pemanipulasi data yang mampu memberikan dalam memecahkan sebuah masalah maupun kemampuan dalam berkomunikasi untuk masalah dengan keadaan yang terstruktur maupun tidak terstruktur. Dalam setiap pengambil keputusan memberikan preferensi yang berbeda, salah satunya dari derajat kepentingan kriteria, maupun preferensi pada bobot tingkat kecocokan setiap altenatif pada kecocokan kriteria [11].

Multi Criteria Decision Making (MCDM) merupakan metode dalam pendukung keputusan digunakan untuk menilai altenatif yang terbaik dari banyaknya pilihan altenatif berdasarkan pada beberapa kriteria tertentu [6]. MCDM memilih altenatif terbaik dari beberapa altenatif yang paling baik serta saling menguntungkan dimana performasi dalam bermacam-macam criteria [7]. Salah satu metode oleh MCDM untuk pendukung keputusan adalah Elimination Et Choix Traduisant La RealitA (ELECTRE) [8].

\section{LANDASAN TEORI}

Sistem Pengambil Keputusan untuk metode Electre pada system ini dapat melakukan sebuah proses eliminasi dan menghasilkan altenatif terbaik yang lebih mendominasi altenatif lainya dalam merekomendasikanya [9]. Metode Electre melakukan klasifikasi altenatif yang masuk kedalam sebuah kelompok yang direkomendasikan [3].

Penelitian dari [10] menyatakan penggunaan dalam metode Electre untuk menentukan karyawan yang baik sangat cocok dilakukannya, karena adanya system ini yang dapat memberikan rekomendasi keputusan untuk menentukan karyawan atau pegawai yang layak mendapatkan reward penghargaan dalam karirnya, sehingga dapat menjadikan motivasi oleh pegawai dalam berkarir. Penelitian selanjunya oleh [3] pada penelitian Metode Electre dapat dipergunakan dalam sebuah kelompok data altenatif yang masuk ke kategori kelompok yang direkomendasikannya, untuk data yang tidak termasuk dalam kategori direkomendasi akan tereleminasi.

Penelitian lain juga dilakukan oleh [8] menyatakan dalam penelitianya metode Electre ini dapat menghasilkan rekomendasi sebuah destinasi wisata yang terbaik di yogyakarta, rekomendasi destinasi wisata itu berdasarkan altenatif dan kriteria yang. Selanjutnya penelitian oleh [12] menyatakan dalam penelitian metode electre, kinerja dalam metode ini untuk mengambil keputusan dalam penerimaan beasiswa yang berdasarkan kriteria yang diberikan sudah cukup baik dan akurat. Hal tersebut terlihat dari 
hasil penelitian dalam pengujian dimana dalam metode ini mampu mengelimisani peserta yang tidak memenuhi syarat kriteria dalam penerimaan beasiswa dan metode ini hanya menapilkan nama peserta yang hanya memenuhi syarat dalam penerimaan beasiswa.

\section{METODE PENELITIAN}

Tahapan Studi dalam penelitian ini terdiri dari metode pengumpulan data, melakukan analisis leteratur Review, Penentuan Altenatif, Penentuan Kriteria, Konstrukksi Hirarki Permasalahan, Melakukan Penerapan Metode Electre, Perangkingan dari beberapa Altenatif dan yang terakhir melakukan seleksi pondok pesantren dengan metode electre. Sehingga dalam kerangka ini dapat menjadikan suatu sistem yang sesuai yang diharapkanya.

\section{Alur Penelitian}

Alur Penelitian dapat dilihat pada gambar 1 dibawah ini.

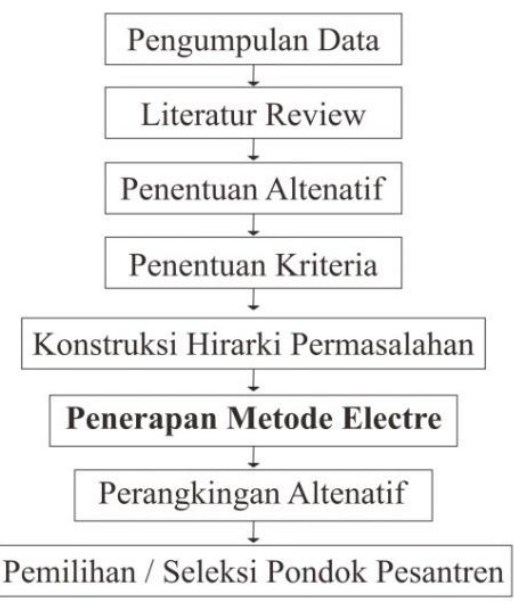

Gambar 1. Alur Penelitian

\section{Electre (Elimination Et Choix Traduisant La RealitA)}

Electre adalah system metode pengambil Keputusan yang multi criteria yang didasarkan oleh konsep out rangking dengan menggunanakan dari beberapa perbandingan yang berpasangan altenatif dan beberapa kriteria yang dibutuhkanya.. Metode Electre ini digunakan pada saat kondisi dalam altenatif yang kurang sesuai dengan kriteria. Sehingga altenatif akan tereliminasi dan akan menampilkan altenatif yang sesuai dengan kriteria [6].

Metode pada konsep hubungan outranking yang pertama kali menggunakan konsep ini memperkenalkan pada metode Electre adalah Roy (1968) dan Benayoun et al. (1966) pada saat itu, dari metode Electre ini dikembangkan berdasarkan masalah dimana ada pada saat itu dan untuk menentukan solusi terhadap kernel atau digunakan dalam perangkingan urutan altenatif, tingkat signifikasi kriteria harus diperhitungkan dan informasi profesional, Tzeng(2011) [2]. 


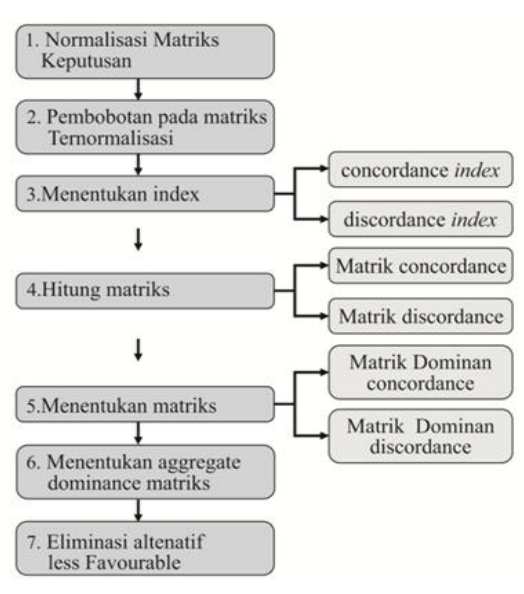

Gambar 2. Diagram Blok Langkahlangkah metode electre.

\section{PENGUJIAN DAN ANALISIS}

Analisis Sistem Pendukung Keputusan untuk pemilihan Pondok Pesantren diproses oleh Metode Electre berdasarkan kriteria dan altenatif yang dipilihnya. Untuk menyelesaikan permasalahan tersebut ada beberapa langkah-langkah dalam metode Electre.

\section{Analysis Kriteria}

Parameter atau Kriteria dalam pemilihan Pondok Pesantren yang digunakan sebagai perbandingan adalah sebagai berikut :

Tabel 1. Kriteria

\begin{tabular}{ccc}
\hline No & Kriteria & Keterangan \\
\hline 1 & C1 & Kurikulum \\
2 & C2 & Fasilitas \\
3 & C3 & Ekstrakulikuler \\
4 & C4 & Biaya \\
5 & C5 & Jarak \\
\hline
\end{tabular}

Sedangkan tingkat kepentingan untuk menentukan ranting kecocokan pada setiap kriteria yang sudah ditentukan oleh penulis dinilai dengan satu sampai lima, yaitu :

$1:$ Sangat Buruk

2 : Buruk

3 : Cukup

4 : Baik

5 : Sangat Baik

\section{Analisis Altenatif}

Berdasarkan data yang berhasil penulis kumpulkan maka penulis mengambil sample 3 pondok pesantren dan didapatkan hasil nilai dari kecocokan antara altenatif berdasarkan masing-masing kriteria. Berikut tabelnya :

Tabel 2. Ranting kecocokan pada setiap Kriteria

\begin{tabular}{ccccccc}
\hline \multirow{2}{*}{$\begin{array}{c}\text { Kod } \\
\text { e }\end{array}$} & \multirow{2}{*}{ Altenatif } & \multicolumn{5}{c}{ Kriteria } \\
\cline { 2 - 6 } & C1 & C2 & C3 & C4 & C5 \\
\hline A1 & PP Al Itqon & 4 & 4 & 5 & 4 & 5 \\
A2 & PP Al Asror & 5 & 4 & 4 & 5 & 2 \\
A3 & PP Madinah & 4 & 5 & 3 & 4 & 3 \\
& Munawwaroh & & & & & \\
\hline
\end{tabular}

Sedangkan disini menentukan bobot prefrensi yang dinilai dari satu sampai lima, berikut bobot preferensi :

1 : Sangat Rendah

$2:$ Rendah

3 : Cukup

4 : Tinggi

5 : Sangat Tinggi

Dalam penelitian ini, penulis memberikan bobot preferensai pada pemilihan pondok pesantren adalah seagai berikut : 
a. Kriteria Kurikulum $(\mathrm{C} 1)=5$

b. Kriteria Fsilitas $(\mathrm{C} 2)=4$

c. Kriteria Ekstrakulikuler $(\mathrm{C} 3)=3$

d. Kriteria Biaya $(\mathrm{C} 4)=3$

e. Kriteria Jarak (C5) = 3

Maka bobot preferensi yang digunakan $\mathrm{W}=(5,4,3,3,3)$

Untuk

menyelesaikan permasalahan pada pemilihan pondok pesantren dengan metode electre akan dilakukan dengan tahapan-tahapan perhitungan sbagai berikut :

a. Tahap ke-1 : Membuat perbandingan berpasangan yang dinormalisasikan.

pada tahap pertama ini melakukan normalisasi terhadap keputusan berdasarkan data altenatif yang diperoleh pada table 4.2 rating kecocokan pada setiap kriteria. Normalisasi pada langkah pertama ini dilakukan dengan menggunakan persamaan dari setiap atribut diubah menjadi nilai yang comparable.rumusnya sebagai berikut :

$$
R \imath \jmath=\frac{x \imath \jmath}{\sqrt{\sum_{l=\imath}^{m} x^{2_{\imath \jmath}}}}
$$

Sehingga hasil normalisasi dari matriks $\mathrm{R}$ adalah :

$x=\left[\begin{array}{lllll}0,5298 & 0,5298 & 0,7071 & 0,5298 & 0,8111 \\ 0,6622 & 0,5298 & 0,5656 & 0,6623 & 0,3244 \\ 0,5298 & 0,6622 & 0,4242 & 0,5298 & 0,4866\end{array}\right]$

b. Tahap ke-2 : Pembobotan terhadap Matriks yang telah di Normalisasi.
Tahap selanjutnya pada pembobotan pada matriks dari hasil normalisasi yang didapatkan dari proses sebelumya menggunakan bobot pada pengambilan keputusan. Pada kolom terhadap matriks $\mathrm{R}$ dikalikan oleh bobot-bobot yang ditentukan dengan pembuat keputusan. Langkah ini dilakukan pembobotan dengan menggunakan pada persamaan, sebagai rumusnya adalah :

$$
=\left[\begin{array}{ccccc}
0,5298 & 0,5298 & 0,7071 & 0,5298 & 0,8111 \\
0,6622 & 0,5298 & 0,5656 & 0,6623 & 0,3244 \\
0,5298 & 0,6622 & 0,4242 & 0,5298 & 0,4866
\end{array}\right]
$$

Sehingga diperoleh matriks $\mathrm{V}$ hasil perkalian antara $\mathrm{R}$ dengan $\mathrm{W}$ :

$V=\left[\begin{array}{lllll}2,6490 & 2,1192 & 2.1213 & 1,5894 & 2,4333 \\ 3,3113 & 2,1192 & 1,6970 & 1,9868 & 0,9733 \\ 2,6490 & 2,6490 & 1,2727 & 1,5894 & 1,4599\end{array}\right]$

c. Tahap ke-3 : Menentukan Concordance dan Discordance.

Pada tahapan selanjutnya menentukan concordance dan discordance yang ditentukan dari himpunan concordance dan discordance. Dengan menentukan perbandingkan terhadap nilai matriks oleh hasil dari pembobotan yang berdasarkan pada persamaanya, rumusnya concordance sebagai berikut :

$C_{k l}=\left\{j, v_{k_{j}} \geq v_{i_{j}}\right\}$ Untuk $j=1,2, \ldots \ldots, n$ 
Dengan

menggunakan

persamaan diatas, didapatkan hasil

$$
\begin{aligned}
& C_{12}=\left\{j, v_{1_{j}} \geq\right. \\
& \left.\quad v_{2_{j}}\right\} \text { Untuk } j \\
& =1,2,3,4,5 \\
& =(2,3,5) \\
& \begin{aligned}
C_{13}=\left\{j, v_{1_{j}} \geq\right. & \left.v_{3_{j}}\right\} \text { Untuk } j \\
& =1,2,3,4,5 \\
& =(1,3,4,5)
\end{aligned}
\end{aligned}
$$

Sebaliknya, komplementer dari subset ini adalah disconcordance, sebagai berikut :

$$
D_{k l}=\left\{j, v_{k_{j}}<v_{i_{j}}\right\} \text { Untuk } j=1,2, \ldots, n
$$

Dengan menggunakan persamaan diatas, didapatkan hasil

$$
\begin{array}{r}
D_{12}=\left\{j, v_{1_{j}}<v_{2_{j}}\right\} \text { Untuk } j \\
=1,2,3,4,5=(4) \\
D_{13}=\left\{j, v_{1_{j}}<v_{3_{j}}\right\} \text { Untuk } j \\
=1,2,3,4,5=(2)
\end{array}
$$

d. Tahap ke-4 : Menentukan nilai dari elmen-elmen matrik Concordance dan Discordance

- Concordance

Tahapan ini menentukan matriks Concordance yang berdasarkan pada himpunan matriks Concordance yang didapatkan dari proses sebelumnya, berikut rumus persamaan yang dapat digunakan dalam menghitung matriks Concordance adalah :

$$
C_{k l}=\sum_{j \in C_{k l}} W_{j}
$$

\section{Dengan} menggunakan persamaan diatas, didapatkan hasil :

$$
\begin{aligned}
C_{12} & =W 2+W 3+W 5 \\
& =4+3+3=10 \\
C_{13}= & W 1+W 3+W 4 \\
& +W 5 \\
= & 5+3+3+3=14
\end{aligned}
$$

Maka yang dihasilkan dari perhitungan adalah :

$$
\left[\begin{array}{ccc}
- & 10 & 14 \\
12 & - & 11 \\
12 & 7 & -
\end{array}\right]
$$

- Discordance

Tahapan ini menghitung discordance yang berdasarkan pada himpunan disconcordance yang didapatkan pada proses sebelumnya. Dengan membagi pada maksimum selisih criteria. Berikut rumus dari persamaan disconcordance adalah :

$$
=\frac{d_{k l}}{\max \left\{\left|V_{k j}-V_{i j}\right|\right\} j \in D_{k l}}
$$

Dengan menggunakan persamaan diatas, didapatkan hasil : 


$$
\begin{aligned}
& d_{12} \\
& =\frac{\max \{|1,5894-1,9868|\}}{\max \left\{\begin{array}{c}
|2,6490-3,3113|:|2,1192-2,1192| \\
|2,1213-1,6970|:|1,5894-1,9868|
\end{array}\right\}} \\
& =0,2721 \quad:|2,4333-0,9733|
\end{aligned}
$$

Selanjutnya dengan menggunakan rumus dan cara perhitungan yang sama maka akan menghasilkan matriks discordance sebagai berikut :

$$
\left[\begin{array}{ccc}
- & 0,2721 & 0,5443 \\
1 & - & 0,8 \\
1 & 1 & -
\end{array}\right]
$$

e. Tahap ke-5 : Menentukan matriks dominan concordance dan discordance.

- Concordance

Pada tahapan ini, menghitung matriks dominan concordance yang berdasarkan himpunan matriks concordance didapatkan dari proses himpunan sebelumnya. Ada beberapa lagkah persyaratan yang dipergunakan dalam menghitung nilai-nilai matriks dominan Concordance adalah :

$$
f_{k l}=\left\{\begin{array}{l}
1, j i k a C_{k l} \geq c ̧ \\
0, j i k a C_{k l}<c ̧
\end{array}\right\}
$$

dimana setiap elmen matriks concordance dibandingkan dengan threshold (c) persamaan sebagai berikut :

$=\frac{\sum_{k=1}^{m} \sum_{1=1}^{m} c k l}{m(m-1)}$

$$
\begin{aligned}
& =\frac{10+14+12+11+12+7}{3(3-1)} \\
& =\frac{66}{6}
\end{aligned}
$$

Seingga diperoleh matriks dominan concordance sebagai berikut :

$$
F=\left[\begin{array}{ccc}
- & 0 & 1 \\
1 & - & 1 \\
1 & 0 & -
\end{array}\right]
$$

- Discordance

Tahapan ini menghitung matriks dominan discordance dimana matriks discordance didapakan dari proses sebelumya. Pada tahapan ini sama menggunakan bantuan dari nilai threshold, yang didapatkan dari persamaan sebagai berikut ini :

$g_{k l}=\left\{\begin{array}{l}1, j i k a C_{k l} \geq \underline{\mathrm{d}} \\ 0, j i k a C_{k l}<\underline{\mathrm{d}}\end{array}\right\}$

Dimana d adalah threshold yang akan diperoleh dari persamaan berikut adalah :

$$
\begin{gathered}
D=\frac{\sum_{k=1}^{m} \sum_{1=1}^{m} d k l}{m(m-1)} \\
=\frac{0,2721+0,5443+1+0,8+1+1}{3(3-1)} \\
=\frac{4,6164}{6}=0,7694
\end{gathered}
$$

Sehingga diperoleh matriks dominan discordance adalah sebagai berikut : 


$$
G=\left[\begin{array}{ccc}
- & 0 & 0 \\
1 & - & 1 \\
1 & 1 & -
\end{array}\right]
$$

f. Tahap ke-6: Menentukan aggregate dominance matriks.

Pada tahapan ini dalam menentukan aggregate dominance matriks dilakukan perkalian dari niali matriks f dengan nilai matriks g yang didapatkan dari hasil nilai matriks Concordance dan Discordance, sehingga dapat menghasilkan nilai dari aggregate dominance matriks. Berikut rumus persamaan dari aggregate dominance matriks :

$$
\begin{gathered}
e_{k l}=f_{k l} x g_{k l} \\
E=f x g \\
=\left[\begin{array}{ccc}
- & 0 & 1 \\
1 & - & 1 \\
1 & 0 & -
\end{array}\right] x\left[\begin{array}{ccc}
- & 0 & 0 \\
1 & - & 1 \\
1 & 1 & -
\end{array}\right] \\
=\left[\begin{array}{ccc}
- & 0 & 0 \\
1 & - & 1 \\
1 & 0 & -
\end{array}\right]
\end{gathered}
$$

Sehingga hasil dari perhitungan matriks aggregate dominance pada pemilihan pondok pesantren metode electre adalah sebagai berikut :

Tabel 3. Hasil Perhitungan

\begin{tabular}{ccccc}
\hline $\begin{array}{c}\text { Kode } \\
\text { Altenatif }\end{array}$ & A1 & A2 & A3 & Ranking \\
\hline A1 & - & 0 & 0 & 3 \\
A2 & 1 & - & 1 & 1 \\
A3 & 1 & 0 & - & 2 \\
\hline
\end{tabular}

Tabel 4. Altenatif

Kode Altenatif
A1 Pondok Pesantren Al Itqon
A2 Pondok Pesantren Al Asror
A3 Pondok Pesantren Madinah Munawwaroh

g. Tahapan ke-7: Eliminasi altenatif yang Less Favourable.

Pada Langkah ini dilakukan tahapan eliminasi pada setiap altenatif yang mempunyai nilai (1) paling sedikit pada Aggregate Dominance matriks. Pada hasil tahapan mengeliminasi ini adalah altenatif yang mendapatkan nilai (1) terbanyak pada aggregate dominance matriks. Dari proses dalam perhitungan Aggregate matriks sebelumnya menunjukan jika pondok pesantren $\mathrm{Al}$ Itqon tidak mendapatkan nilai 1 sedangkan pondok pesantren Madinah Munawwaroh mendapatkan nilai 1 sebanyak 1 . Sehingga system pendukung keputusan untuk pemilihan pondok pesantren akan merekomendasikan ke pondok pesantren Al Asror dengan mendapatkan nilai 1 sebanyak 2. Dengan demikian pada system pendukung keputusan pada metode electre ini, dimana kemudian menjadi keputusan pemilihan pondok pesantren berdasarkan pada criteria dan altenatif yang bisa memungkinkan hasil yang tepat.

\section{Volume 6 Nomor 1 | April 202133}




\section{IMPLEMENTASI}

Adapun untuk tampilan antarmuka dalam implementasi Multi criteria decission marking tersebut dapat dilihat dibawah ini. Pada gambar sebagai Berikut :

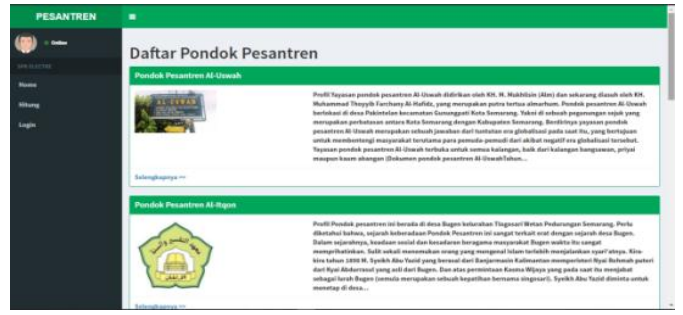

Gambar 3. Tampilan antar muka halaman utama

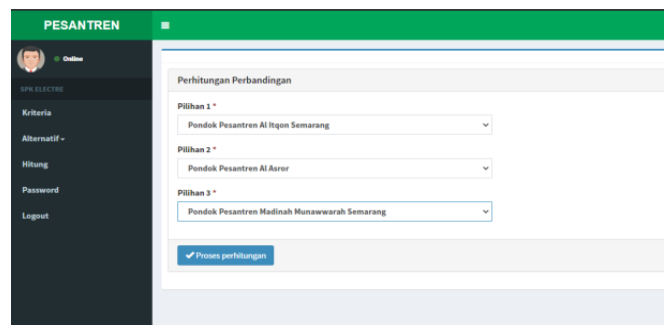

Gambar 4. Tampilan Antar Muka Halaman Hitung

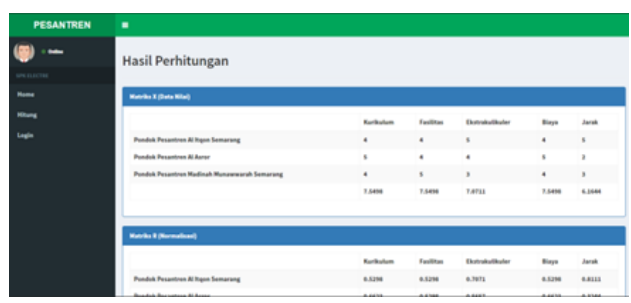

Gambar 5. Tampilan Antar Muka Halaman Hasil Perhitungan

\section{PENGUJIAN SISTEM WHITE BOX DAN BLACK BOX}

Pengujian sistem ini ialah pengujian sistem yang berfokuskan pada pengelolahan serta pengetesan alogaritma serta pula logika dari jalanya sistem tersebut. Pada pengujian white box ini hendak diambil contoh pada halaman login admin.

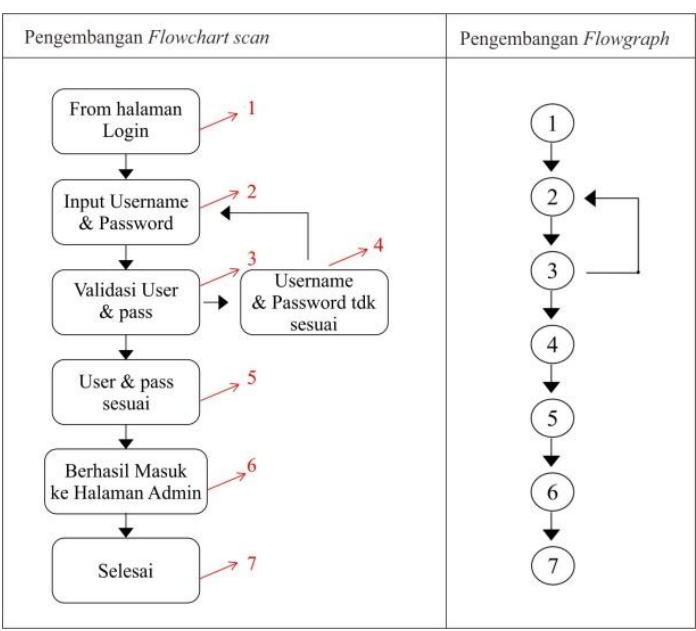

Gambar 6. Pengujian White Box Flowchart dan Flowgraph

Pada pengujian berikutnya dalam balck box hendak ditampilakan memakai table rujukan dan masukan keluaran untuk mengaplikasikan pengujian sikap sistem dikala diberikan masukan, serta bila keluaran yang dihasilkan yakni yang sesuai kosnsep yang diharapkan hingga bisa diberikan jika sistem sudah lolos dari pengujian black box.

Tabel 5. Pengujian Black Box

\begin{tabular}{|c|c|c|c|}
\hline Kasus Uji & $\begin{array}{l}\text { Hasil yang } \\
\text { diharapkan }\end{array}$ & $\begin{array}{l}\text { Hasil yang } \\
\text { didapatkan }\end{array}$ & Status \\
\hline Kriteria & True & True & $\checkmark$ \\
\hline Altenatif & True & True & $\checkmark$ \\
\hline $\begin{array}{c}\text { Nilai } \\
\text { Altenatif }\end{array}$ & True & True & $\checkmark$ \\
\hline Hitung & True & True & $\checkmark$ \\
\hline Password & True & True & $\checkmark$ \\
\hline Logout & True & True & $\checkmark$ \\
\hline
\end{tabular}

Volume 6 Nomor 1 | April $2021 \quad 34$ 


\section{KESIMPULAN}

Pada penelitian ini menghasilkan sebuah sistem untuk menentukan pemilihan pondok pesantren terbaik di semarang. Metode Electre dalam system ini mengeliminasi dari beberapa altenatif dan dapat menghasilkan altentif yang lebih mendominasi pada altenatif lainya dalam merekomendasi pondok pesantren di semarang. Hasil pengujian kualitas secara fungsional sistem menggunakan white box dan black box testing sesuai perancangan yang yang telah dibangun.

\section{DAFTAR PUSTAKA}

[1] Syafe'i. Imam "Pondok Pesantren : lembaga pendidikan pembentukan karakter" jurnal Pendidikan Islam, Vol. 8, No 1 2017

[2] Nurwasito. Heru, Suherti Prahesti, dan dian eka ratnawati "Sistem Rekomendasi Pemilihan Sekolah Menengah Atas (SMA) Sederajat Kota Malang Menggunakan Metode AHP- ELECTRE dan $S A W$ ' Jurnal teknologi informasi dan ilmukomputer, Vol. 4, no. 1, Maret 2017 : 25-30.

[3] Hadikurniawati. W, Irfak Lahumu Darojat, "Implementasi Metode AHP Pada Sistem Pendukung Keputusan Penyeleksian Nasabah Pinjaman Kredit" MSI (Jurnal Manajemen Informatika dan Sistem Informasi) Vol. 4 No. 1 January 2021
[4] Sukur. M dan Susanto, "Sistem Pendukung Keputusan Penilaian Kinerja Karyawan Menggunakan AHP pada PT. NAYATI", Dinamika Informatika, Vol.5, No.2, Oktober 2013.

[5] Firdausa, Aji Prasetya Wibawa, dan Utomo Pujianto,"Model Sitem Pendukung Keputusan Pemilihan Sekolah Menggunakan Metode SAW', SNTIM, STMIK AMIKOM Yogyakarta, 6-7 Februari 2016.

[6] Setiawan. Fahmi, Fatma Indriani dan Muliadi,"Implementasi metode ELECTRE pada Sistem Pendukung Keputusan SNMPTN Jalur Undangan", Jurnal Ilmu Komputer, Vol.02, No.02 September 2015.

[7] Pramudhita, Agung N., Hadi Suyono dan Erni Yhudaningtyas,"Penggunaan alogaritma Multi Criteria Decission Marking dengan metode Topsis dalam penempatan Karyawan", Junal EECCIS, Vol.9, No.1, Juni 2015.

[8] Marlinda. Linda, "Sistem Pendukung Keputusan Pemilihan Tempat Wisata Yogyakarta Menggunakan Metode Elimination Et Choix Traduisant La Realita (Electre)", SNST, Fakultas 
Teknik Universitas

Muhammadiyah Jakarta, 8

November 2016.

[9] Fauzi. wildan," Sistem Pendukung

Keputusan Penerima Bantuan

Dana Rutilahu Dengan

Menggunakan Metode Electre.",

SENTIKA, Yogyakarta 2016.

[10] Andriani. Tuti, "Sistem

Pendukung Keputusan Pemilihan

Karyawan Terbaik Dengan

Metode Electre (Studi Kasus

Swalayan Maju Bersama)",

Jurnal Multimedia dan Teknologi

Informasi, Vol.01, No.2 2019.

[11] Hadikurniawati. W, Franki

Zakariya dan Taufiq dwi

Cahyono, "Implementasi Metode

Analytic Hierarchy Process

Dalam Multi Attribute Decision

Making Pemilihan Produk"

Prosiding Sendi_U, 2019.

[12] Beni Satria, Abdi Santoso, Mery

Sri Wahyuni, Haikal Nando

Winata, Selly Annisa, Zulkarnain

Lubis dan Abdullah Muhazzir, "penerapan metode electre sebagai sistem pendukung keputusan dalam penerimaan beasiswa", Buletin Utama

Teknik, Vol.14, No.3, Mei 2019. 